\title{
Anterior cervico-vaginal tear along with posterior bladder wall rupture: a rare case report
}

\author{
Rekha Sachan $^{1}$, Munna Lal Patel ${ }^{2}$, Meenakshi Singh $^{1}$, Preeti Tyagi $^{1}$
}

\begin{abstract}
${ }^{1}$ Department of Obstetrics and Gynecology, King George's Medical University, Lucknow, Uttar Pradesh, India
${ }^{2}$ Department of Medicine, King George's Medical University, Lucknow, Uttar Pradesh, India
\end{abstract}

Received: 18 September 2016

Accepted: 15 October 2016

\author{
*Correspondence: \\ Dr. Rekha Sachan, \\ E-mail: drrekhasachan@gmail.com
}

Copyright: (C) the author(s), publisher and licensee Medip Academy. This is an open-access article distributed under the terms of the Creative Commons Attribution Non-Commercial License, which permits unrestricted non-commercial use, distribution, and reproduction in any medium, provided the original work is properly cited.

\begin{abstract}
A 25 year old female presented to our emergency as a case of G3P2+0 (2A and $\mathrm{H})$, full term pregnancy with intrauterine foetal demise with obstructed labour with severe anaemia. In view of obstructed labour with severe anaemia suspicion of rupture uterus was raised. Abnormal contour of abdomen also raised suspicion of bladder tumour. Here emergency caesarean section was done, peroperatively she was diagnosed as a case of anterior cervicovaginal rupture along with posterior bladder wall rupture which is a rare entity. Uterine closure was done along with anterior cervico-vaginal wall with posterior bladder wall repair. This repair was done through trans- bladder route. Unique finding of this case was tear of anterior cervico-vaginal region with associated posterior bladder wall tear without rupture of uterus despite of obstructed labour in multiparous women. Most probable cause behind this type of injury is impacted head in neglected or obstructed labour responsible for ischemia and necrosis.
\end{abstract}

Keywords: Bandl's Ring, Bladder rupture, Cervico-vaginal tear, Obstructed labour

\section{INTRODUCTION}

In spite of so much improvement in obstetric care management, obstructed labour is still challenging. In present scenario obstructed labour is one of the common causes of maternal and perinatal morbidity and mortality in less developed countries. Obstructed labour accounting for about $8 \%$ of all maternal deaths in developing countries. ${ }^{1}$ Various studies reported maternal mortality between $1 \%$ and $13 \%$, and perinatal mortality between $74 \%$ and $92 \% .^{2,3}$ Obstructed labour responsible for about half of all maternal deaths, it affect mainly primigravida and grand multipara. ${ }^{4,5}$

Bladder rupture following caesarean section is well documented complication. The rapid increase in the number of caesarean sections and therefore repeated caesareans is expected to increase the number of intraoperative complications. ${ }^{6,7}$
Typically bladder injuries are identified intraoperatively. In case of suspected injuries methylene blue infusion into the bladder through urine catheter helps to identify the leak. Cystoscopy is also helpful to identify exact site of injury. ${ }^{1}$ In such type of cases surgical repair usually done early to avoid formation of fistulas, mainly vesicouterine and vesicovaginal fistula. ${ }^{8}$ Women who suffered from prolonged or obstructed labor developed anatomical or functional damage of the pelvic floor leading to pelvic organ prolapsed, vesicovaginal fistula, and urinary or fecal incontinence. Here I am describing a case of intact uterus with posterior bladder wall injury in unscarred uterus, is a rare complication of obstructed labour.

\section{CASE REPORT}

A 25 year old female presented to emergency as a case of $\mathrm{G} 3 \mathrm{P} 2+0 \quad(2 \mathrm{~A}$ and $\mathrm{H})$, full term pregnancy with intrauterine foetal demise with obstructed labour with 
severe anaemia. On admission patient was tachypnoeic, dehydrated,with PR120beats/min., BP 110/74mmHg, Temperature was $100.4^{\circ} \mathrm{F}$ and severe Pallor .

On Abdominal examination fundal height was full term with cephalic presentation, bandl's ring was present. Lower part of abdomen was so much distended making impression of a huge bladder tumour. Liquor was less in amount and foetal heart rate was absent .She had strong uterine contractions. (Figure 1)

Per Vaginal Examination showed fully dilated and effaced cervix with deeply impacted foetal head in pelvis, with caput +3 and moulding of grade 3 , pelvis was adequate. On investigation - $\mathrm{Hb}-6.9 \mathrm{gm} \%$, total leucocyte count $-9800 / \mathrm{mm}^{3}$, differential leucocyte countpolymorph- $79 \%$, lymphocyte- $18 \%$, eosinophyl- $3 \%$, monocyte- $1 \%$ and basophyil- 0 , platelet count200000/cumm, blood urea 36.4gm/dl, S. Creatinine 0.67 $\mathrm{mg} / \mathrm{dl}$, Prothrombin time $14.1 \mathrm{sec}$, International normalized ratio $1.21, \mathrm{~S} . \mathrm{Na}^{+} 142.4 \mathrm{mmol} / \mathrm{L}, \mathrm{S} . \mathrm{K}^{+} 4.65$ $\mathrm{mmol} / \mathrm{L}, \mathrm{S} . \mathrm{Ca}^{++} 5.49 \mathrm{mg} / \mathrm{dl}$.

After catheterization $200 \mathrm{cc}$ of hematuric urine was drained out. Decision of emergency caesarean section was taken after proper counselling and written informed consent in view of maternal prognosis and intrauterine foetal demise.

Abdomen was opened through right paramedian incision. A bandl's ring was present and bladder was high up and oedematous (Figure 2). It was really difficult to make out demarcation between upper and lower uterine segment and uterovesical fold was identified, small nick given over it and bladder was pushed down. After opening the uterus baby was delivered by patwardhan technique. After removal of placenta, foley bulb was seen within vagina instead of bladder.

For confirmation, second assistant was asked to do Per Vaginal examination, urethra was found intact and no urine was drained in the catheter and Foley bulb was present within the vagina. A rent of approximately 3 centimeter was present in the anterior vaginal wall and involving posterior bladder wall up to bladder neck through this rent foley catheter entered into the vagina. Anterior wall of bladder was completely intact. Anterior cervico-vaginal portion was torn and difficult to find out tissue for repair (Figure 3).

Opinion was taken from urosurgeon anterior vaginal wall was repaired by vicryl number 2-0 on round body needle followed by bladder repair done via 3-0 vicryl on round body needle. This complete repair was done via transvesical route. Bilateral ureteric orifices identified and cannulated. Supra-pubic catheter (SPC) was placed and omentum interposed between bladder and vagina. SPC and bilateral ureteric catheter exteriorised. Per operatively two units packed red blood cells was transfused.

\section{DISCUSSION}

During first stage of labour vaginal trauma is very rare, it is mostly seen in neglected case or women receiving poor intrapartum care. If patient left undiagnosed or untreated obstetric fistulae may appear secondary to obstructed labour. However, this is exceedingly rare in developed world. ${ }^{9}$

As per literature (Medline, 19/12/2011) only three cases of primary vaginal rupture during labour were reported. In first case posterior vaginal wall tear occurred during spontaneous labour at 28 weeks of gestation because she suffered with vaginal atresia. ${ }^{7}$

In the other case, a patient was induced with oxytocin at 39 weeks of gestation and had rupture of her anterior vaginal wall and posterior bladder wall, during prolonged second stage. ${ }^{8}$

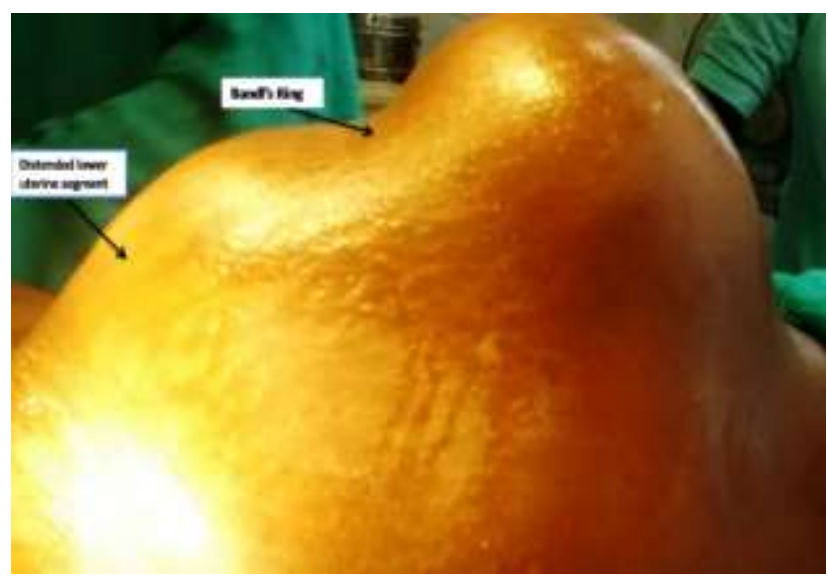

Figure 1: Signs of obstructed labour, bandl's Ring and distended lower uterine segment.

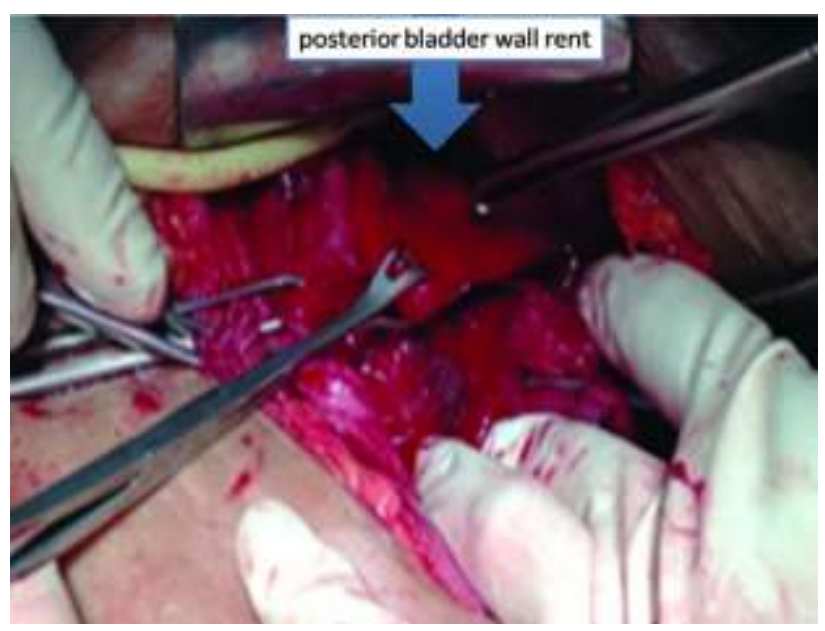

Figure 2: Cervicovaginal portion and posterior bladder wall rent.

In both cases, the rupture was only discovered during caesarean section, after delivery of the baby. 
In our case also anterior vaginal wall tear along with posterior bladder wall rupture was diagnosed per operatively.

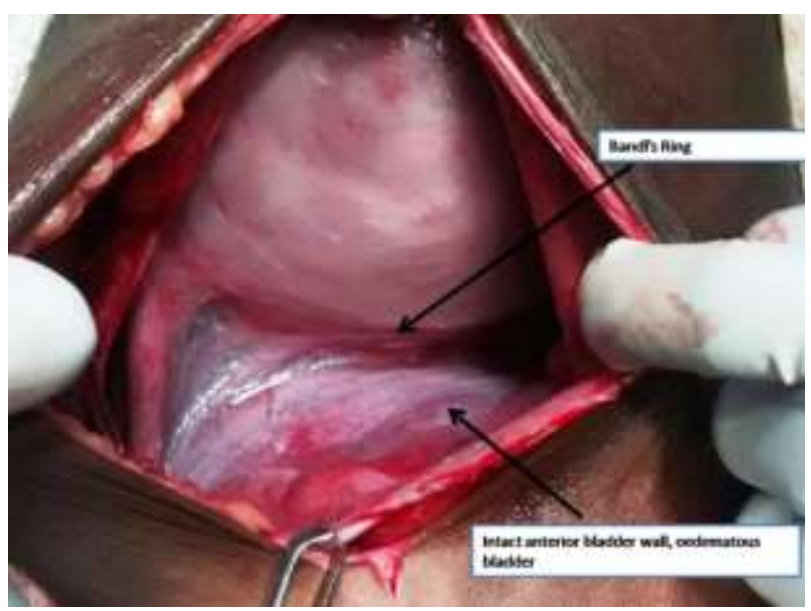

Figure 3: Oedematous and high-up bladder with intact anterior bladder wall.

However, in above cases a common sign is the presence of decelerations on the cardiotocograph. This is also one of the most common indicator of uterine rupture in our case patient came with intrauterine foetal demise. ${ }^{10}$

Sign and symptoms with complete uterine rupture are change in uterine shape, cessation of uterine contractions, non-reassuring foetal heart tracing, lack of the presenting part on pelvic examination and even maternal shock. ${ }^{11}$ Gross hematuria is the most common sign of uterine rupture associated with bladder rupture. In present case uterine contour was changed with presence of bandle's ring and no urine was drained out after catheterization.

Prolonged labor with pressure of the fetal head on the vesico-vaginal junction may have led to ischemia, which coupled with disrupting forces, responsible for vaginal laceration and complete vesico-vaginal disruption as seen in our case. ${ }^{12}$ Pathophysiology of the bladder rupture in intrapartum period includes sustained pressure from the foetal head against the bladder during forceful uterine contractions which may lead to pressure necrosis of the bladder dome. ${ }^{13}$

Typically bladder injuries are identified intraoperatively. In case of suspected injuries methylene blue infusion into the bladder through urine catheter helps to identify the leak. Cystoscopy is also helpful. ${ }^{1}$ The surgical repair should be done early to avoid formation of fistulas, mainly vesicouterine and vesicovaginal fistulas. ${ }^{13}$

Obstructed labour is a preventable condition and quite common in developing countries, so there is a need of improvement in antenatal care services with proper utilization of health services will help to overcome this devastating complication.
Incidence of bladder rupture associated with uterine rupture was $8-15 \%$ in various studies. ${ }^{9,13}$ It is mostly found during caesarean section done for failed vaginal birth after caesarean (VBAC). ${ }^{14}$ Bladder rupture along with vaginal rupture in unscarred uterus has been rarely reported.

Early recognition of prolonged labour before going into obstruction and safe abdominal or vaginal delivery can decrease the incidences of maternal and neonatal morbidity and mortality and it also reduces the complication like vesicovaginal fistula formation.

\section{CONCLUSION}

Poor referral system, low socioeconomic status, illiteracy, and inadequate antenatal care services responsible for obstructed labour. The caesarean section is preferred mode of delivery. Destructive operations are not preferred because of their immediate and remote complications.

\section{Funding: No funding sources \\ Conflict of interest: None declared \\ Ethical approval: Not required}

\section{REFERENCES}

1. Cron J. Lessons from the developing world: Obstructed laborand the vesico-vaginal fistula. Med Gen Med. 2003;5:24.

2. Rahman MH, Akter HH, Khan Choudhury ME, Yusuf HR, Rochat RW. Obstetric deaths in Bangladesh 1996-1997. Int J Gynaecol Obstet. 2002;77:161-9.

3. Hofmeyr GJ, Say L, Gülmezoglu AM. WHO systematic review of maternal mortality and morbidity: The prevalence of uterine rupture. BJOG. 2005;112:1221-8.

4. Cox ML. Contracted pelvis in Nigeria. J Obstet Gynaecol Br Emp. 1963;70:487-94.

5. Arrow S, Hamlin C, Wall L. Obstructed labor injury complex: obstetric fistula formation and the multifaceted morbidity of maternal birth trauma in the developing world. Obstet Gynecol Surv. 1996;51:568-74.

6. Allen AM, Lakin T, Shobeiri SA. Transmural vaginal-to-bladder injury froman obstructed labor pattern. Obstetrics and Gynecology. 2011;117:46870.

7. Young B, Takoudes T, Lim KH. Rupture of the posterior cul-de-sac during spontaneous labor. Obstetrics and Gynecology. 2010;115:414-7.

8. Spaulding LB. Delivery through the maternal bladder during trial of labor. Obstetrics and Gynecology. 1992;80:512-4.

9. Lydon-Rochelle M, Holt VL, Easterling TR, Martin DP. Risk of uterine rupture during labor among women with a prior cesarean delivery. N Engl J Med. 2001;345(1):3-8. 
10. Guise JM, McDonagh MS, Osterweil P. Systematic review of the incidence and consequences of uterine rupture in women with previouscaesarean section. British Medical Journal. 2004;329:19-25.

11. Klutkee JJ, Klutke CG. Simultaneous bladder and uterine rupture at the time of attempted vaginal birth after cesaren section. Int J urogynecol .1992:3:83-6.

12. Normal Labour: Holland and Brews Manual Obstetrics. 2008:246-338.

13. Shipp TD, Zelop CM, Repke JT. Intrapartum uterine rupture and dehiscence in patients with prior lower uterine segment vertical and transverse incisions. Obstet Gynecol. 1999;94:735-40.

14. Alison GC, Molly JS, David MS. Risk factors for bladder injury in patients with a prior hysterotmy.Obstet Gynecol. 2008;112(1):116-20.

Cite this article as: Sachan R, Patel ML, Singh M, Tyagi P. Anterior cervico-vaginal tear along with posterior bladder wall rupture - a rare case report. Int J Reprod Contracept Obstet Gynecol 2016;5:4480-3. 